\title{
Relationship between Introversion and Extroversion Personality and Learning Styles of UPSI Student
}

\section{Faza Reza Mohd Yunos ${ }^{1}$, Mohd Razimi Husin ${ }^{1}$}

${ }^{1}$ Faculty of Human Development, Kampus Sultan Azlan Shah, Universiti Pendidikan Sultan Idris. Tanjung Malim, Perak, Malaysia.

Article History

Received:

14.10.2021

Revised:

23.11.2021

Accepted:

17.12 .2021

*Corresponding Author:

Mohd Razimi Husin

Email:

razimi@fpm.upsi.edu.my

This is an open access article, licensed under: $\mathrm{CC}-\mathrm{BY}-\mathrm{SA}$

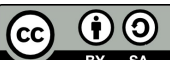

Abstract: This research is conducted to identify the Relationship between Introversion and Extroversion Personality with Learning Style of UPSI students. This research is conducted to identify the relationship of the Introversion and Extroversion personality affect the by the Visual, Auditory and Kinesthetic (VAK) learning style. In addition, suitable activities are also discussed to suit the needs of introversion and extroversion personality. A total of 233 second year UPSI students were selected in this research. The data was collected using questionnaire and divided into two parts. The first part is the identification of the introversion and extroversion personality of the respondent and the second part is the learning style of the respondent which are divided into 3 parts which are Visual, Auditory and Kinesthetic. The data collected was then analysed using Pearson Correlation test. The Pearson Correlation test shows no significant between the introversion and extroversion personality of the respondent and the VAK learning style due to the $p=.730$. Suitable activities consist of hands-on and group activities is among the major suggestion collected from the respondent. In conclusion, although there is no significant between Introversion and Extroversion personality and VAK learning style, the teacher should pay attention to their students' behavior in a learning environment to ensure the engagement of the students towards the lesson taught by them.

Keywords: Extroversion, Instructional Strategies and Activities, Introversion, Learning Style. 


\section{Introduction}

In the field of education, several field is talked such as behavior in school [1] [2] [3] [5] [6] [7], teaching and learning style [8] [9] [10] [11] [12] [13] [14] [15] [16] [17] [18] [19] [20], academic [21] [22] [23] [24 25] [26] [27]. Learning style is the theory related to teaching. Learning style is the learner's ability in comprehending the knowledge received. Fatt [28] said that learning style is related to how an individual perceived the knowledge transferred to them. How a learner comprehend an information is depended on their mental readiness and how the information is process.

The research on introvert and extrovert personality involves how the learner perceive a knowledge and the task that they prefer when acquiring knowledge [29] [30]. According to Jung [31] there are two type of personality which are introvert and extrovert. These personality does have inter-related with the concept of learning. Introvert is the relationship between man and internal input or the interaction between a learner and their relationship towards internal information, whereas extrovert between man and external input. This is one of the definition that can be related to introvert and extrovert personalities.

This study is also focusing on the relationship between VAK learning style and the introvert and extrovert personality among higher education students. VAK learning style is an acronym for Visual, Auditory and Kinesthetic modalities [32]. These modalities is used to differentiate each type of learning modalities. For example a Visual learner prefer a learning process through the use of drawing, graph or pictures. An Auditory learner prefer learning using verbal or sound either through a recording or an interaction between learners. Lastly, kinesthetic learner may prefer a hands-on type of learner through field trip or trial and error about an information.

The general objective of this study is to identify the characteristics of introverted and extroverted student personality and to identify the effectiveness of these personalities in learning. Other than that, this study will also suggest suitable activities according to each personalities which are the introvert and extrovert. In addition to general objective of this study, the specific objectives are as follows:

- to examine the level of introverted and extroverted personalities among the students.

- to examine the level of visual, auditory and kinesthetic learning style among the students.

- to examine the relationship between introversion and extroversion personality with visual, auditory and kinesthetic students.

- to identify suitable activities that can be used for students which uses introversion and extroversion personality.

\section{Literature Review}

\subsection{Introverts and Extroverts Personalities}

According to Larsen \& Buss [33] personality can be defined as the set of psychological traits and mechanisms within the individual that are organized and relatively enduring and that influence his or her interactions with, and adaptations to, the intrapsychic, physical, and social environments. Friedman \& Schustack [34] defines personality psychology as a scientific study which aims to show how people are individually different due to psychological forces. One of the related theory personality psychology is the type theories which developed by Carl Jung [31]. Type theories according to Jung [31] there are two type of personality which are introvert and extrovert. An extrovert personality consist of the relationship between man and the external input which affect this type of personality. The ability to build up relationship based on the external input which received by the man mind or body developed this type of personality. The extrovert also perceived input as objective and objective data. Whereas an introvert personality consist of the relationship between man and the internal input received. The introvert perceived in as subjective which differentiate themselves from extrovert personality. Through the research of Jung [31], the term introvert and extrovert is used to clarify the personality characteristics differences between these terms. Dossey [35] said that generally, introverts are individuals who embrace solitude by spending time alone; process their thoughts in their head rather than talk them out. The means that introverts often secluded themselves in their own thought process rather than embracing the socialite of the people around them. These personalities will be explained in detail using Carl Jung's personality types. These type which have two parts which is judging function and perceiving function. The judging function which consist of thinking and feeling, whereas the perceiving function consist of sensation and intuition.

Introverted personality in general is about the subjective view of interposes a subjective view between the perception of an object and his own action, which prevents the action from assuming a character that corresponds with the objective situation [31]. This gives the assumptions of an introvert 
personality to be excluded from the society due to the fact that they have their own theory of opinion. However, an introvert personality have their own ability in considering all the factor which helps them in understanding the result of their opinion or the subjective way of understanding an idea which they contemplate in. Overall, the function of thinking, feeling, sensation and intuition of an introverted are the effect of subjective values which develop the process and procedure which produce an introvert personality as a whole.

Extroverted personality differ from an introvert personality. One point of view of an extroverted personality would have an objective view on the stimulus that they receive [31]. This is different than introverted personality who view are subjective. This also gives the opinion of an extrovert to be more expressive rather than introverted personality. Jung [31] extraverted action is recognizably related to objective conditions. Which further explained the objective values which are more dominant for an extroverted personality. Objective conditions is related to environment of an extrovert which influences the action and thinking process of an extroverted personality [36]. As an overall, the extrovert personality is depended and influenced by objective values rather than subjective value. Due to this an extrovert mostly concern on the objective part of such as external data which developed to be useful for extrovert personality.

\subsection{VAK Learning Styles}

Dunn \& Dunn [37] suggest the definition of learning style as "in which individuals begin to concentrate on, process, internalize, and retain new and difficult academic information". Another definition of learning styles refer to a range of competing and contested theories that aim to account for differences in individuals' learning needs. The learning style used by each individuals to one another [38].

VAK learning style is an acronym for visual, auditory and kinesthetic modalities [32] where Barbe and his colleagues suggest that these three modalities can be used to determine the learning style used by learner in their learning process. The VAK model consist of the module of visual, audio and kinesthetic. These module represent the input medium for information gathering. Barbe [32] suggest that these modalities can work as independently or mixed together. However, their usage may change due to other circumstances which affect the individuals learning style.

Jayakumar et al [39] suggested that visual learner will have the tendency to prefer see or observed things, including pictures, diagrams, demonstrations, displays, handouts, films, flip chart and type of visual stimuli. These type of learner prefer to "see" the information or idea that are transferred to them. Rafida [40] visual learners like to learn through written language and other visual representations of information.

Kostelnik et al [41] defined an auditory learner to be depended on listening and speaking as the primary way of learning. They process the information via sound. These individuals discover information through listening and interpreting information by the means of pitch, emphasis and speed. These individuals gain knowledge from reading out loud in the classroom and may not have a full understanding of information that is written [42]

Reese \& Dunn [43] define kinesthetic learners as students who require whole-body movement to process new and difficult information. Individuals that are kinesthetic learners learn best with an active "hands-on" approach. These learners favor interaction with the physical world. Due to the nature of kinesthetic learner, they are easily distracted by other environmental factors as mentioned by Gilakjani [42] in which most of the time kinesthetic learners have a difficult time staying on target and can become unfocused effortlessly.

\subsection{Instructional Strategies and Activities}

Instructional is defined as teaches people something [44]. The process of instructional is the process of teaching something to people. According to Oxford dictionary [43] the word strategy is defined as the process of planning something. Therefore,

Instructional strategies can be defined as a process of planning or designing a method of teaching people. Instructional strategies vary among its implementation and design [45]. Different group of learner required different style of teaching. Gentry et al [45] talks about the different instructional strategies is one of the way for an educator to adapt to the needs of their learner and help them to improve themselves in the process of learning. According to Wiggins [46] studies on the use of both game-based learning (GBL) and gamification in tertiary education in communications, although GBL 
is one of the strategy used by communications instructor, the usage of GBL is still under-utilized. This is due to reasons such as unfamiliarity and the low rate of usage among instructors.

\section{Methodology}

The objective of this research is to identify the relationship between extrovert and introvert personality with VAK learning style of a student. Therefore, 233 second year UPSI students are chosen to answer these research objective. These sample are chosen through random sampling. Simple random sampling will give the population an equal chance in sampling [47].

The research instrument chosen is through a survey consist of three parts. The survey or questionnaire is chosen due to the large number of sample and short period of research conduct. The first part consist of the demographic profile of the respondent. The second part consist of the respondent introvert and extrovert preferences. The items used in this part is used to differentiate introvert and extrovert personality preferences among the respondents. The third part consist of question related to the learning style of the respondent.

\section{Results and Discussion}

The level of Introversion and Extroversion for this sample is shown in Table 1. Majority of the respondents have introverted personality compared to extroverted personality. Other factors such as environment [31] can affect the creation of this personality among the respondents. This also contributed in their learning process and how they would interact in a learning acquisition environment such as schools or academic institute as a whole.

Table 1. Introversion and Extroversion

\begin{tabular}{lcc}
\hline \multicolumn{1}{c}{ Personality } & Frequency & Percent \\
\hline Introvert & 135 & 57.9 \\
\hline Extrovert & 98 & 42.1 \\
\hline Total & 233 & 100 \\
\hline
\end{tabular}

This is shown by the number of introverts is higher than extroverts. This also because of the advancement of technology where virtual reality and social media are used more often than face-toface interaction.

The level of Visual, Auditory and Kinesthetic learning style for this sample is shown in Table 2. Majority of the respondents preferred the visual learning style compared to other learning style. This is because the usage of images or pictures help them develop a mental image of the lesson and thus ease the process of retaining the lesson. In addition, kinesthetic is the second learning style used by the students followed by auditory learner. This is because of the usage of hands-on in their learning process is much preferred by the respondents compared to the usage of auditory via verbal and sound. Verbal and sound only cannot help the students to remember the lesson in progress compared to hands-on experienced which will be imprinted on their long term memory.

Table 2. Visual, Auditory and Kinesthetic Learning Style

\begin{tabular}{ccc}
\hline Personality & Frequency & Percent \\
\hline Visual & 113 & 48.5 \\
\hline Auditory & 54 & 23.2 \\
\hline Kinesthetic & 66 & 28.3 \\
\hline Total & 233 & 100 \\
\hline
\end{tabular}


There is no significant relation relationship between introversion and extroversion personality with Visual, Auditory and Kinesthetic learning style among the chosen sample as shown in Table 3. The Pearson correlation test shows the value of $\mathrm{p}=.730$ which is more that the significant value of $\mathrm{p}=0.05$. This shows that Introverts and Extroverts personality does not affect VAK learning style of the respondents.

Although the suggested activities are specific to a personality, some of the activities can be used for extrovert and introvert personality. For example, a short case study or group activities. An example of short case study a small research regarding the individual in the classroom. This will engage the extrovert personality in engaging with their classmates and the introvert personality with planning the case study for a themed selected by the teacher. Group activities should include the introvert and extrovert personality in the group. An example of group activities is role play or gamebased activity for a topic of their chosen. Some of the examples of a game-based games is Kahoot which is an online quiz creation game which can be use by the students. Other than that, the respondents suggested the usage of hands-on activities or the usage of technology during the teaching and learning process.

\section{Conclusion}

As a conclusion, the four objectives of this research are answered. The level of introverted and extroverted personality as well as the level of visual, auditory and kinesthetic learning style among the students are shown in the results of this research. The indication of the relationship between personality and learning style shows that there is no significant among to each other. This relationship does not affect the students learning capability and the knowledge acquisition as a whole. Lastly, suitable activities are also gathered and analyzed for this research. The suitable activities are separated to three parts which is for an introverted personality students, extroverted personality students and a combination of introverted and extroverted personality students. The combination of introverted and extroverted instructional strategies is the most applicable to cater a wide range of learning personality and learning style due to its nature to accommodate the needs of this learners.

\section{References}

[1] M. R. Husin, N. A. N. Sufizi, N. F. N. Nasarudin, A. U. Yuslam, S. A. Zainal, A. A. Aspanizam, M. H. M. Bakhari, N. S. H. C. Aziz, S. N. A. Razak, M. H. M. Aini, "Faktor Utama Vandalisme dalam Kalangan Pelajar di Sekolah", Journal of Humanities and Social Sciences, vol. 2, no. 2, pp. 52-61, Aug. 2020.

[2] M. R. Husin, N. S. S. M. Suhairi, W. N. W. Aziz, W. M. A. Zukifli, N. A. Ismail, E. H. M. Hata, S. R. S. M. Rashid, V. Segar, F. S. Effendy, "Masalah Berpasangan-Pasangan dalam Kalangan Pelajar Sekolah", Journal of Humanities and Social Sciences, vol. 2, no. 1, pp. 1-12, Apr. 2020.

[3] N. I. M. Isa, M. R. Hussin, N. H. F. A. Rahim, W. N. I. W. Izham, Nur Atasya Izati Bakeri, Farah Nurhafiza Shamsul Anuar, Najiha Mohbob, "Gejala Membuli dalam Kalangan Pelajar Sekolah", Journal of Humanities and Social Sciences, vol. 2, no. 1, pp. 22-33, Apr. 2020.

[4] G. Chong, M. R. Husin, A. R. Hamid, B. Azahar, M. Muzaffa, F. D. A. Kemchi, N. E. M. A., Z. Zaharudin, M. A. Ismail, A. N. M. Norazni @ M. Yasin, M. A. Azizan, "Masalah Vape di Sekolah Dalam Kalangan Awal Remaja", Journal of Humanities and Social Sciences, vol. 2, no. 1, pp. 34-46, Apr. 2020.

[5] N. N. S. H. Ashaari, S. N. Sumadi, N. A. Salleh, N. I. Ismail, N. A. H. Adenan, and M. R. Husin, "Masalah Pergaulan Bebas dalam Kalangan Remaja Sekolah", International Journal of Humanities, Management and Social Science, vol. 2, no. 1, pp. 38 - 50, Jun. 2019.

[6] L. H. M. Amin, M. R. A. Hafiz, M. N. A. Kamarulzalis, A. H. Ibrahim, N. M. Taib, N. H. Ramlan, M. R. Husin, "Masalah Kecelaruan Tingkah Laku: Ponteng Sekolah", International Journal of Humanities, Management and Social Science, vol. 2, no. 1, pp. 51 - 64, Jun. 2019.

[7] N. Y. Yung, N. I. Rosli, M. A. A. M. Salleh @ Sukri, F. N. S. A. Hamid, N. N. M. Robi, Nurul N. Rosly, M. R. Husin, "Gejala Buli Secara Fizikal yang Semakin Berleluasa di Sekolah", International Journal of Humanities, Management and Social Science, vol. 2, no. 1, pp. 65 - 75, Jun. 2019.

[8] R. Hashim and M. H. Mohamad Yatim, "Hubungan Antara Motivasi dan Penerimaan Dengan Pencapaian Akademik Pelajar Dalam Pembelajaran Menggunakan M-Pembelajaran di Kolej 
Vokasional", International Journal of Humanities, Management and Social Science, vol. 2, no. 2, pp. 89 - 94, Dec. 2019.

[9] M. Mansor, W. A. Wan Adnan, and N. Abdullah, "A Step-by Step Process in Designing Personalized Reading Content for Slow Learner Children", International Journal of Humanities, Management and Social Science, vol. 2, no. 2, pp. 95 - 102, Dec. 2019.

[10] M. R. Husin, N. M. Hassan, V. Y. Z. Sheng, A. S. M. Tormizi, N. S. A. Zulkapli, M. George, R. Rosli, N. I. R. A. M. Hishamuddin, N. S. Shaharudin, C. S. Adampai, "Perspektif Guru Terhadap Pembelajaran Pelajar Remaja", Journal of Humanities and Social Sciences, vol. 3, no. 1, pp. 40-49, Apr. 2021.

[11] J. M. Asio, "Sources of Information, Training Needs, Preparation and Response to Disaster of Selected Communities in Central Luzon, Philippines", International Journal of Humanities, Management and Social Science, vol. 4, no. 1, pp. 30-38, Jun. 2021.

[12] M. Farhan, S. M. Hamil, N. N. Azmi, N. U. J. Roslid, N. N. Zainal, N. B. Kamaruddin, N. I. Hamizi, N. Z. Ismawi, M. R. Husin, "Masalah Pembelajaran untuk Pelajar Pendidikan Khas: Dana dan Prasarana", International Journal of Humanities, Management and Social Science, vol. 3, no. 1, pp. 1-10, Jun. 2020.

[13] N. Laili, S. E. Purwanto, and F. Alyani, "Pengaruh Model Penemuan Terbimbing Berbantu LKPD terhadap Kemampuan Pemahaman Konsep Matematis Siswa SMPN 6 Depok", International Journal of Humanities, Management and Social Science, vol. 2, no. 1, pp. 14 - 37, Jun. 2019.

[14] N. M. Hassan, N. A. N. F. M. Noor, Y. Thasarathan, Q. N. Zainudin, N. S. A. Zainur, Nurul R. N. M. Rizuaden, N. A. M. Fauzi, N. Tumin, N. A. S. M. Jefri, "Perspektif Guru Terhadap Kemahiran Berfikir Aras Tinggi dalam Kalangan Pelajar", Journal of Humanities and Social Sciences, vol. 3, no. 2, pp. 50-56, Aug. 2021.

[15] N. Abdul Rahim, N. A. Meor Fadzir, N. A. H. Zaimal, F. F. Arias Yahaya, Z. I. Zainol, and M. R. Husin, "Implikasi Gaya Pembelajaran Koperatif Subjek Sains Bagi Murid Tahap Dua di Sekolah Kebangsaan Bandar Baru Rawang", Journal of Humanities and Social Sciences, vol. 3, no. 2, pp. 57-66, Aug. 2021.

[16] L. Hernandez, "Strengths and Challenges of Distance Learning Modalities in the New Normal: Basis for Intervention Program", Journal of Humanities and Social Sciences, vol. 3, no. 2, pp. 80-87, Aug. 2021.

[17] M. Z. Mohd Nawi and M. A. Mohamed Noor, "Meningkatkan Kemahiran Mengingat Lima Hukum Asas Tajwid Dalam Tilawah Al-Quran", Journal of Humanities and Social Sciences, vol. 3, no. 1, pp. 23-32, Apr. 2021.

[18] N. Laili, "Hubungan Adversity Quotient dan Hasil Belajar Matematika Peserta Didik dalam Pembelajaran Jarak Jauh di SMP”, Journal of Humanities and Social Sciences, vol. 3, no. 1, pp. 33-39, Apr. 2021.

[19] S. N. Mail and L. F. Md Ibharim, "Pengaruh Sikap Terhadap Pelajar di UPSI Apabila Menggunakan Aplikasi Permainan Atas Talian", Journal of Humanities and Social Sciences, vol. 2, no. 3, pp. 82-87, Dec. 2020.

[20] Z. Mohd Adnan and J. Hamid, "Kesan Model Polya Dalam Pembelajaran Algoritma Dalam Kalangan Pelajar: Satu Kajian Kes", Journal of Humanities and Social Sciences, vol. 2, no. 3, pp. 88-92, Dec. 2020.

[21] N. F. Mat Daud, N. A. S. Mat Yusoff, N. H. Mohd Azmi, S. Z. K. Mohd Asri, N. Z. Manisha Zaidi, and M. R. Husin, "Kerja Sambilan Mempengaruhi Ketidakhadiran Pelajar Tingkatan 3", Journal of Humanities and Social Sciences, vol. 3, no. 2, pp. 67-79, Aug.

[22] J. M. R. Asio, "The Relationship between Academic Procrastination and Academic Performance of Freshmen Students from a Teacher Education Institution", Journal of Humanities and Social Sciences, vol. 2, no. 3, pp. 105-115, Dec. 2020.

[23] A. Ismail, N. Z. Mohamed Zain, and H. Mat Zin, "A Simple Survey on Attitude of Computer Science Diploma Students towards STEM", International Journal of Humanities, Management and Social Science, vol. 2, no. 2, pp. 76 - 88, Dec. 2019.

[24] Nur Syazlina Hanim, Jasmine Anak Jang, Nur Hana Afifa Jamal, Florance Duya Low, Salina Rentap, Nicorsons Anak Fabian, Gilbert Anak Gordion, Mohd Razimi Husin, "Pelajar Berkecerdasan Tinggi dalam Kalangan Pelajar Kelas Rancangan Khas", International Journal of Humanities, Management and Social Science, vol. 2, no. 1, pp. 1 - 13, Jun. 2019. 
[25] C. Ifeakor, and A. I. Odo, "Analysis of the Marxist Theory on the Abolition of State: Its Implication to Nigeria Educational System", Journal of Humanities and Social Sciences, vol. 2, no. 2, pp. 62-68, Aug. 2020.

[26] N. M. Shahril Khuzairi, M. S. Sidhu, and Z. Che Cob, "Learning Analytics and Teaching Analytics: The Similarities and Differences", International Journal of Humanities, Management and Social Science, vol. 3, no. 2, pp. 52-58, Dec. 2020.

[27] T. Tripura, "Issues and Challenges Faced by the Indigenous Students of Tripura in Primarylevel to Higher Education: An overview", International Journal of Humanities, Management and Social Science, vol. 3, no. 2, pp. 59-67, Dec. 2020.

[28] P. T. J, Fatt, "Understanding the learning Styles of Students: Implications for Educators," International Journal of Sociology and Social Policy, vol. 20, no. 11, pp. 31-45, 2000.

[29] W. Jialing, "The Relationship between Learners' Personality Traits and EFL Learning," SinoUS English Teaching, vol. 16, no. 4, pp. 135-142, 2019.

[30] P. Akhavan, M. Dehghani, A. Rajabpour, and A. Pezeshkan, "An investigation of the effect of extroverted and introverted personalities on knowledge acquisition techniques," VINE Journal of Information and Knowledge Management Systems, vol. 46, no. 2, pp. 194-206, 2016.

[31] C. Jung, Psychological Types. London, United Kingdom: Routledge, 2016.

[32] W. B. Barbe, and M. N. Milone, "What We Know About Modality Strengths," Educational Leadership, vol. 38, no. 5, pp. 378-380, 1981.

[33] R. Larsen, and D. M. Buss, Personality Psychology. New York, United States: McGraw-Hill Publishing, 2009.

[34] H. S. Friedman, and M. W. Schustack, Personality: Classic Theories and Modern Research. Boston, MA: Allyn and Bacon, 2016.

[35] L. Dossey, "Introverts: A Defense", Explore: The Journal of Science and Healing, vol. 12, no. 3, pp. 151-160, 2016.

[36] M. R. Husin, N. H. Hadi, E. M. Slanjat, S. W. Hussin, N. Ja'afar, V. Sofia Leonard, J. S. Richard, S. Edwin, "Pelajar Introvert di Sekolah", Journal of Humanities and Social Sciences, vol. 1, no. 1, pp. 1-21, 2019.

[37] R. S. Dunn and K. J. Dunn, Teaching Secondary Students through Their Individual Learning Styles: Practical Approaches for Grades 7-12. New Jersey, United States: Prentice Hall, 1993.

[38] F. Coffield, D. Moseley, E. Hall and K. Ecclestone, Learning styles and Pedagogy in Post-16 Learning: A Systematic and Critical Review. Londok, UK: Learning and Skills Research Centre London, 2004.

[39] N. Jayakumar, A. Suresh, M. Sundaramari and D. P. Prathap, "Understanding learning style variations among undergraduate students," Journal of Extension Education, vol. 28, no. 4, 2017.

[40] T. Rafida, "The Influence of Using Vak (Visual, Auditory, Kinesthetic) Learning Model on The Students'achievement in Writing Short Story Text at Second Grade Smp It Al- Hijrah 2 Deli Serdang," Vision, vol. 13, no. 13, pp. 2018.

[41] M. J. Kostelnik, A. K. Soderman, A. P. Whiren, and M. Rupiper, Developmentally Appropriate Curriculum: Best Practices in Early Childhood Education (3rd edition). New York, United States: Merrill NJ, 2004.

[42] A. P. Gilakjani, "Visual, Auditory, Kinaesthetic Learning Styles and Their Impacts on English Language Teaching," Journal of studies in education, vol. 2, no. 1, pp. 104-113, 2012.

[43] V. L. Reese and R. Dunn, "Learning-Style Preferences of a Diverse Freshmen Population in a Large, Private, Metropolitan University by Gender and GPA," Journal of College Student Retention: Research, Theory \& Practice, vol. 9, no. 1, pp. 95-112, 2007.

[44] O. E. Dictionary, Online Oxford English Dictionary (OED). [Online]. Available: https://en.oxforddictionaries.com/definition/education. [Accessed: 2020].

[45] R. Gentry, A. P. Sallie and C. A. Sanders, "Differentiated Instructional Strategies to Accommodate Students with Varying Needs and Learning Styles. [Online]. Available: https://files.eric.ed.gov/fulltext/ED545458.pdf. [Accessed: 2020].

[46] B. E. Wiggins, "An Overview and Study on the Use of Games, Simulations, and Gamification in Higher Education," International Journal of Game-Based Learning (IJGBL), vol. 1, no. 1829, 2016.

[47] G. Darussalam and S. Hussin, Metodologi Penyelidikan Dalam Pendidikan, Amalan dan Analisis Kajian. Kuala Lumpur: Universiti Malaya, 2016. 